\title{
Communication, Transparency, Accountability: Monetary Policy in the Twenty-First Century
}

Otmar Issing

\begin{abstract}
This article is a revised English translation of the Thünen Lecture, given at the Annual Congress of the Verein für Socialpolitik, September 29, 2004, in Dresden, Germany.
\end{abstract}

Federal Reserve Bank of St. Louis Review, March/April 2005, 87(2, Part 1), pp. 65-83.

\section{COMMUNICATION: PAST AND PRESENT}

1 ow do agents deal with new information that may be of relevance to others? How do they convey their knowledge to the public? And what are the effects of such communication? Two very different historical examples illustrate the persistent relevance of this question.

In $67 \mathrm{BC}$, as piracy posed an ever greater threat to the supply of grain, the Roman authorities assigned command of a huge naval force to Gnaeus Pompeius, who then rid the Mediterranean of pirates within 40 days (see Issing, 1985). One year later, in his first political speech, Marcus Tullius Cicero asserted that the mere announcement of Pompeius's nomination for that mission had sent the price of grain in Rome plummeting on the same day.

In 1860, Lady Wilberforce, wife of the Bishop of Worchester, learned of Charles Darwin's new theory. She is said to have exclaimed: "Descended from the apes! Us! How awful! Let us hope that it is not true, but if it is, let us pray that it will not become generally known!"

In the first case, the mere announcement of the measure had the desired effect, fully in line with rational expectations theory. The second scenario highlights the intention to essentially ignore unwelcome information, or at least keep it in check.
In present times, as in the past, the role of information can hardly be overestimated. In our age of new media technology, the increase in the speed, scope, and volume of communication has been dramatic. These days, no significant institution-be it public or private, be it a central bank or a sports club—can survive without a press office. Media advisers are ubiquitous: They thrive on the belief that, if need be, even poor results can be given a positive spin, while incontestable successes will fail to have the desired effect if not communicated in the right way.

Since their beginning, churches have been especially aware of the importance of communication; and at the start of a new religion, the main aim is often to spread the gospel by word and deed, by sermon and miracle. ${ }^{1}$ Do something good and talk about it. Be transparent-but only about the good deed?- - and be accountable for your actions.

In the language of economists, such maxims quickly translate into complicated formulae and complex models. This should come as no surprise to anyone, as behind nearly every simple wisdom there lies an intricate web of complex relations.

This paper starts off with some general remarks and then moves on to discuss questions

1 “And the gospel must first be published among all nations" (Mark 13:10, King James Version).

Otmar Issing is a member of the Executive Board of the European Central Bank (ECB). The author thanks Philipp Hildebrand and Manfred J.M. Neumann, as well as Klaus Adam, Klaus Masuch, Wolfgang Modery, Wolfgang Schill, and Bernhard Winkler, for their valuable help and Philippine Cour-Thimann and Wolfgang Modery for the compilation of both tables. The author also benefited crucially from discussions with Mervyn King on these issues.

(c) 2005, The Federal Reserve Bank of St. Louis. 
of communication policy and transparency in relation to a central bank. To what extent does a central bank have to be transparent to fulfill the accountability requirements of a democracy? What is the impact of communication and transparency on monetary policy efficiency and, hence, on monetary policy objectives? Finally, what are the implications for the communication policy of the European Central Bank?

\section{THE MIRAGE OF UNLIMITED TRANSPARENCY}

Today, there is a general consensus among central bankers that transparency is not only an obligation for a public entity, but also a real benefit to the institution and its policies. For a long time, however, central banks followed quite a different tradition. Sometimes unwittingly, sometimes quite deliberately—and very much in keeping with the prevailing zeitgeist-they evinced an air of discretion, to put it mildly. In the words of a later scathing critic,

Central Banking [has been] traditionally surrounded by a peculiar and protective political mystique. The political mystique of Central Banking was, and still is to some extent, widely expressed by an essentially metaphysical approach to monetary affairs and monetary policy-making...The mystique thrives on a pervasive impression that Central Banking is an esoteric art. Access to this art and its proper execution is confined to the initiated elite. The esoteric nature of the art is moreover revealed by an inherent impossibility to articulate its insights in explicit and intelligible words and sentences. Communication with the uninitiated breaks down.

(Brunner, 1981)

There was a time when the Bank of England could almost be classified as the epitome of reticence vis-à-vis the public, and it was for this reason that back in 1928 it was subject to increasing criticism (King, 2004). The Deputy Governor at the time, Sir Ernest Harvey, defended the Bank's posi- tion before the Macmillan Committee (Committee on Finance and Industry, 1931, p. 27-31):

Committee member Gregory: "I should like to ask you, Sir Ernest, whether you have ever considered the possibility of the Bank issuing an Annual Report on the lines of the Annual Report of the Federal Reserve Board, for instance?"

Deputy Governor Harvey: "I confess I am sometimes nervous at the thought of publication unless it is historical. The question is whether, when it is merely historical it is of any particular value, or whether from the fact that it is issued from the central bank undue importance may be attributed to certain things that are stated, more importance than perhaps they merit..."

Committee member Keynes: "Arising from Professor Gregory's questions, is it a practice of the Bank of England never to explain what its policy is?"

Harvey: "Well, I think it has been our practice to leave our actions to explain our policy."

Keynes: "Or the reasons for its policy?"

Harvey: "It is a dangerous thing to start to give reasons."

Keynes: "Or to defend itself against criticism?"

Harvey: "As regards criticism, I am afraid, though the Committee may not all agree, we do not admit there is need for defence; to defend ourselves is somewhat akin to a lady starting to defend her virtue."

Imagine a central banker or representative of whatever institution trying to use this kind of argument today! Society demands transparency from public institutions, with the result that laws and even constitutions include appropriate provisions. ${ }^{2}$ In the extreme, transparency means that

\footnotetext{
2 See Article I-46 and Article I-49 of the draft version of the "Treaty establishing a Constitution for Europe." Almost 60 countries have legislation on the freedom of information, determining which information is to be made generally accessible by public institutions. Similar legislative proposals are being discussed in 40 additional countries.
} 
absolutely any information available should be published. Any selection of information, any retention of knowledge, would constitute a violation of the principle of transparency and would thus breach the requirement to be accountable to the public.

Particularly in the case of institutions that are granted the legal status of independence, the demands for unlimited, absolute transparency as a necessary counterpart of independence arise almost inevitably. Furthermore, does additional information not in any case have a welfareenhancing effect? Disregarding the costs of procuring and processing information, does more information not increase the expected utility of decisionmakers (Blackwell, 1953)? Thus, a central bank should be well advised and even be legally obliged to publish all internal documents and data, in particular those that are instrumental in its monetary policy decisions and relate to its status of independence. Such obligations of accountability would then also encompass information regarding the decisionmaking process itself, any differences of opinion, consensus agreements, a majority voting behavior, etc.

Like any other public institution, a central bank in a democratic society must fulfill certain transparency requirements vis-à-vis its citizens. Like any other institution? Just as an aside: Does the call for the publication of minutes also extend to government cabinet meetings or proceedings in the courts of justice? Why not?

Back to central banks and monetary policy: If communication and transparency requirements are understood in this legal and political sense, the extent to which information is transmitted would be determined solely by the level of demand on the part of the public. The central bank would have no justification to limit its supply.

Pursuing this train of thought further, one could easily imagine regular live broadcasts of the meetings of central bank decisionmaking bodies. One could, of course, object that in this case discussions and straw votes would then simply be moved outside public meetings. However, if one accepts the postulate of absolute transparency, then the issue here is simply one of enforceability of a legal obligation.
The further one pushes this postulate of unlimited disclosure of information to its logical conclusion, the more questions and objections arise. Can the television broadcast alone provide all the relevant information about the decisionmaking process? Does one not also need to know why one member voted one way and why another member voted the other way? Is it perhaps due to differences in the underlying economic philosophies-a Keynesian as opposed to a monetarist approach? Or maybe it is simply due to different levels of preparation for the meeting? Would there then not also be a need to televise the preparatory meetings of the policymakers with their staff? And likewise the preparations for these preparatory meetings? Where would the cutoff point be?

The quest for absolute, unlimited transparency about the decisionmaking process thus quickly runs into practical difficulties. By contrast, the case for publishing facts and figures seems to be a fairly straightforward one-or at least at first glance. But, even here, transparency can hardly be tantamount to an obligation to publish everything immediately. What stands in the way of such an approach is the sheer volume of information that would be unleashed, running the risk of blocking the communication channel and overwhelming recipients. ${ }^{3}$ A strict interpretation of a comprehensive notion of the requirement for disclosure could indeed allow an agent-and this is not just a hypothetical consideration-to use communication to deliberately orchestrate an information overflow in order to act essentially unobserved behind a veil of staged confusion. Mind you, we are talking here only about an overflow of correct information.

The data frequently represent a wide spectrum of conditions, such as how timely they are and how susceptible they are to revision-as well as the frequency and timeliness of those revisions. Moreover, data are often not self-explanatory, as their information content changes depending on the way they are communicated by the sender. For this reason, even if a central bank wanted to, it would not be able to avoid the need to select information, qualify it, and comment on it. This

3 Cf. Shannon's (1948) mathematical theory of communication and its application to macroeconomic and monetary policy issues in Sims (2003) and Adam (2004). 
requirement, however, does not free it from its obligation to render this process as transparent as possible (see, e.g., ECB, 2004).

It is not my aim here to make a caricature of the call for transparency in order to justify an arbitrary limitation of information. In a democracy, public institutions are not only obliged to be accountable for their actions, they must also be transparent in their behavior. This applies not least to a central bank that has been granted extensive legal independence and which therefore is not even indirectly subject to electoral accountability. However, any meaningful discussion on the requirement for transparency cannot ignore the question of what this implies in practice.

Demands for absolute, unlimited transparency are met with instinctive approval, and any doubts raised about it are met with emotional resistance. We must therefore explain very carefully why the requirement for absolute, unlimited transparency carries with it insurmountable limits in both theory and practice. Once an agreement on this conclusion has been reached, it becomes clear that the transparency principle requires considerable interpretation.

\section{TRANSPARENCY AND EFFICIENCY IN MONETARY POLICY}

A famous legal case provides a good illustration of the issues involved. In March 1975, a student at the Georgetown University Law Center, David R. Merrill, filed an action against the Federal Reserve's Federal Open Market Committee (FOMC) under the 1966 Freedom of Information Act to request that it should publish the policy directive and minutes directly after every meeting (see Goodfriend, 1986). Following a judgment from the District Court in favor of the plaintiff and its confirmation by the Court of Appeal, the case was finally referred to the United States Supreme Court. In the end, the Supreme Court decreed that the FOMC should be bound by an immediate publication obligation unless it "would significantly harm the Government's monetary functions or commercial interests." (The reference to "commercial interests" is based on the FOMC's argument that the Treasury would face significantly higher borrowing costs.)

Consequently, the FOMC had to base its case for nonpublication primarily on arguments from monetary and financial theory, which is exactly what Fed representatives tried to do in their statements. In June 1981, the District Court, to which the case had been redirected, ruled in favor of the FOMC. Even though the Fed's arguments at the time did not appear to be completely convincing (Poole, 2003), the Court's decision-perhaps surprisingly—was nevertheless in line with some findings in information theory that show that, in a social context, additional information can actually be detrimental (Hirshleifer, 1971, 1975; Morris and Shin, 2002). Even if more information increases the expected utility of the individual (Blackwell, 1953), this does not necessarily improve outcomes for society as a whole.

To the judge it was "apparent, however, upon reviewing the affidavits that the dispute among the experts in this case [was] not one over facts in any objective sense, but rather [was] a dispute over economic theory. It may in fact be finally reducible to a dispute over proper monetary policy." Consequently, the judge ruled that "insofar as judgement pertaining to the validity of a particular economic theory or the wisdom of a particular policy are entrusted to the FOMC under the auspices of Congress, the Court lacks the expertise necessary to substitute its judgement or that of plaintiff's experts for that of the FOMC."

A legal case thus translated into a dispute over issues of economic theory. The dynamics of this legal battle provide us with insights, however, that can also be aimed at through quite a different route.

Any discussion on the communication and transparency of monetary policy that starts off in abstract terms and in isolation of the actual task of a central bank is bound to lead to misunderstandings. Transparency is not an end in itself; a central bank is not established with the primary objective of communicating with the public. Its mandate either stems directly from the monetary system, as was the case with the gold standard, or is specified by the legislator, which became necessary in times of the paper standard. Today, 
its task - either alone or in connection with other objectives-is generally to maintain price stability or a low level of inflation. In this regard, central banks act as agents in a principal-agent relationship vis-à-vis society at large and in most cases they have been granted independent status in order to better fulfill their mandate. Central bank accountability is therefore centered on the bank fulfilling its mandate, rendering transparency subordinate to their ultimate tasks and objectives. It is precisely with this in mind that central banks in the past have justified their reluctance to release information to the public and their aura of "mystique," as criticized by Brunner. This stance puts them in the territory identified by the U.S. courts. Consequently, central banks are obliged to explain their communication policy; they must justify any withholding of information to the public, such as information about the voting behavior of members of the decisionmaking body, for example. Obviously, their reasons must be related to the fulfillment of their monetary policy task.

The aforementioned remarks of Deputy Governor Harvey in the light of modern information theory offer some interesting insights. He justified his reservations about the usefulness of an annual report by saying that "undue importance may be attributed to certain things that are stated, more importance than perhaps they merit." Recent work on information theory has rediscovered the conflict between public and private information (Morris and Shin, 2002) and, among other things, has shown that public information can result in a crowding out of private information and ultimately a welfare loss. Although no one would question the usefulness of an annual report today, the issue of its content has yet to be resolved.

In addition, Harvey's reasoning that "it has been our practice to leave our actions to explain our policy" is not as foolish as it may initially seem, since it underlines a key aspect of the communication problem. If a monetary policy decision per se were to already include all relevant information, it would simply suffice to announce it in order to comply with transparent communication requirements. This would be the case if monetary policy reacted entirely mechanically to changes in key parameters. Such rigid compliance with a stringent rule would indeed rid monetary policy of all discretionary elements and reduce communication, transparency, and accountability to the publication of the respective decision-provided the public were sufficiently well informed of the rule and that strict adherence thereto were in line with the mandate. This claim is precisely the one made by Milton Friedman, for example, in his well-known k-percent rule (Friedman, 1960). Henry Simons used the motto "Rules versus Authorities" to argue that the influence of individuals on monetary policy decisions should be limited; and, as Walter Eucken postulated, a good monetary constitution should function "as automatically as possible" (Eucken, 1955, p. 257).

Strict adherence to rules solves the problem of communication and transparency to the extent that it does not allow for any discretion or personal influence to be brought to bear in the decision and its communication. Conversely, the public's need for information increases with the level of discretion exercised in the monetary policy decision-the level of personal influence will also rise accordingly - and involves a corresponding need to convey the policy through communication as well as action, thus simultaneously generating a transparency and communication problem.

Interestingly, even apparently simple monetary policy strategies, such as direct inflation targeting, involve considerable communication requirements. In the end, inflation targeting still leaves the central bank a significant amount of discretionary leeway. For example, if inflation deviates from the target rate, the central bank selects the appropriate adjustment path toward the target. The choice of path is left to the central bank and, among other things, depends on the expected impact on real economic activity (Friedman, 2004; McCallum and Nelson, 2004).

Communication and transparency therefore become discretionary issues; that is, they become a balancing act for the central bank, which has to assess the impact of communication on the efficiency of monetary policy. Communication, not least of all, becomes crucial for steering market expectations (Woodford, 2003).

Monetary policy can only fix central bank 
interest rates and therefore has control over only the very short end of the interest rate spectrum. The influence of monetary policy on the long end of the spectrum largely depends on market expectations regarding future central bank decisions and future inflation. Developments across the entire yield curve and decisionmaking behavior of economic agents across all markets depend crucially on expectations as to whether and how the central bank will fulfill its mandate.

\section{Steering Market Expectations}

Short-Term Signaling. The steering of financial market expectations has two dimensions: First, it involves short-term indications on policy inclinations in the run-up to monetary policy decisions. In the simplest case, certain code words suffice to signal an impending decision to market participants. The search for such "codes" is very popular among many market participants. Code words can be readily identified and taken into account in market operations; they can reduce uncertainty in the run-up to meetings of the decisionmaking body, and they can help to avoid errors in the short-term planning of operations and curb the volatility of interest rates. However, with the use of such code words, the central bank puts itself under pressure to honor a quasi-promise. If, in the meantime, its assessment of the situation has changed, owing to new developments, the central bank will be faced with the dilemma of triggering market disturbances if they "disappoint" expectations, even though they may have convincing arguments to justify their reassessment of the circumstances. For this reason, indications about future decisions must always be seen only as conditional commitments. In practice, however, it is likely to prove extremely difficult to communicate this proviso with sufficient clarity. The more straightforward the "announcement" and the simpler the code, the more difficult it will be to explain its conditionality ex ante.

If communication is understood (at least broadly) as the unconditional announcement of future decisions, the financial markets will reflect (or "price in") these expectations. "Thus, statements and policy actions can serve as effective substitutes for one another, at least in the short run" (Kohn and Sack, 2003). It is obvious that a strategy in which announcements take the place of concrete action will become more risky the longer the period over which expectations are to be influenced.

Under no circumstances should a central bank deliberately set out to unsettle the markets or even give false information about its true intentions. The world is unstable enough without a central bank intentionally generating additional uncertainty; greater volatility and ultimately higher risk premia would be a high price to pay. At the same time, the central bank must ensure that it does not end up merely executing the expectations developed in the market.

If monetary policy ends up merely following the markets, it runs the risk of losing sight of its ultimate objective. Monetary policy takes effect via the financial markets, whose agents are directly affected by monetary policy decisions. Misperceptions of monetary policy activity can cost them dearly. Consequently, praise and complaints from the markets have understandably become permanent companions of monetary policy. Central banks are therefore exposed to the temptation of attributing an importance to market reactions that goes beyond their "transmission" interest. Alan Blinder concludes his remarkable book entitled "Central Banking in Theory and Practice" (1998, p. 76) with this warning: "Following the markets too closely...may lead the central bank to inherit precisely the short time horizon that central bank independence is meant to prevent. There is no more reason for central bankers to take their marching orders from bond traders than to take their orders from politicians." In the longer term, however, I believe this conflict will disappear. A central bank can successfully use the markets in the long term only if, in fulfilling its mandate, it gains the confidence not only of the public at large but also of the financial markets.

Longer-Term Consistency. There is, however, a second dimension to the predictability of decisions. In the medium to longer term, it becomes a question of consistency between the sum of individual decisions and the announced longerterm objectives of monetary policy. If such con- 
sistency is achieved, monetary policy is predictable and credible in the long term. Reconciling the two different dimensions of predictability is and will remain one of the main requirements of communication and monetary policy per se.

Ensuring such consistency in decisions relating to its mandate is the key requirement of a central bank's monetary policy strategy. If a central bank pursues a consistent strategy and succeeds in communicating it convincingly, it will play an important role in successfully steering expectations. One element of such a strategy is to provide some (implicit) indication of how monetary policy is likely to deal with exogenous shocks to supply and demand. Another element relates to the potential reaction to such shocks-gradual versus abrupt measures. Providing indications on the monetary policy reaction function enhances predictability over a more medium-term horizon. If a central bank is reliable in this sense, it is much easier for it to gain credibility and win the trust of the public and the markets alike. In this regard, all efforts must focus on anchoring inflation expectations at a level that is in line with the mandate and, where appropriate, with price stability or an inflation target.

As far as steering medium- to longer-term expectations is concerned, credibility is essential. First and foremost, credibility is won through systematic, coherent actions. "A central bank that consistently performs in a particular way will have credibility even if the market has little or no idea of what the objective is or how the central bank achieves it. The saying that 'actions speak louder than words' is particularly true when it comes to credibility. In the final analysis, credibility is earned-there is simply no other way to get it" (Thornton, 2002, p. 11).

A good track record, however, does not eliminate the need for a good communication policy. First, such a track record is not available to a new institution. Second, if the monetary policy strategy is not clearly communicated, there is a tendency for market participants to adjust their longer-term expectations (e.g., their inflation expectations) in line with the current circumstances (i.e., the current inflation rate). If there is no credible strategy in place, economic agents try, by means of an adaptive learning process, to use the available data to second-guess the current thinking of the central bank. Short-term deviations of the inflation rate from the inflation target then result in adjustments to the expected inflation rate. Under such circumstances, determining and implementing monetary policy will become considerably more difficult (see Orphanides and Williams, 2002). The challenge for communication policy is to provide convincing reasons for any deviations from target and to provide reassurance that these developments are only temporary. Long-term inflation expectations that remain in line with the central bank's objective are a confirmation of credibility, which, in turn, facilitates the conduct of monetary policy.

An appropriate strategy, a convincing track record, and thus a consistent communication policy complement each other and are a sign of an effective monetary policy. A clear strategy can also provide stability to the analytical framework and decisionmaking process for monetary policy. After all, the individuals responsible for monetary policy decisions will change over time and there is a need to convince the public that continuity of good policies is ensured.

An important task of a central bank is also to explain to the public the limits of its mandate and abilities to achieve the associated goals. This approach is necessary to avoid raising false expectations that will not be met, resulting in a loss of credibility for central bank policies overall. For example, monetary policy can control inflation only in the medium-to-long term. Volatile components of the price index (e.g., energy and food prices) can lead to significant fluctuations in inflation rates in the short term. The central bank's reputation could be tarnished if the public believed that the central bank was able, on a sustainable basis, not only to guarantee a low level of inflation but also to use monetary policy measures to boost growth and employment.

This highlights a further communication challenge with the public as well as with governments and parliaments. Politicians time and again try to blame central banks for unfavorable macroeconomic developments such as high unemployment and low growth. Maintaining monetary 
stability in the long term, therefore, largely depends on whether or not the central bank wins over public opinion (Issing, 2002).

No doubt, there is significant interest in central bank transparency on both the "supply side," the central bank, and the "demand side," the public.

The public's interest in transparency with regard to monetary policy's fulfillment of its mandate is essentially in line with the central bank's interest in using this channel as a means of enhancing monetary policy efficiency. In an ideal world, the optimum amount of information is determined by the point where the supply and demand curves intersect. ${ }^{4}$ However, the question of where this point is remains difficult to answer in practice.

\section{GENERAL REQUIREMENTS FOR GOOD COMMUNICATION}

Successful communication is one of the greatest challenges for monetary policy. The more convincingly central banks can explain the reasons for their monetary policy decisions to the public, the more effective their monetary policy will be. For this reason central banks publish extensive information about their strategy, analyses, and decisions.

Experience has shown, however, how difficult it is to communicate to the public all information relevant to the decisionmaking process in a way that is not only exhaustive but also clear and comprehensible. Psychological research has pointed to the limits of human information processing skills (Kahneman, 2003). This research has shown, for example, that the weighting of information greatly depends on its intuitive accessibility. Furthermore, information is generally simplified and categorized before it is collated. A central bank's communication policy is therefore faced with the task of conveying the necessary information clearly and with the appropriate emphasis and salience.

At the same time, a central bank must also

\footnotetext{
4 Faust and Svensson (2001) call for the decision regarding the level of transparency to be transferred to society and not left to the central bank. See also Neumann (2002).
}

convey that monetary policy decisions are complex and that the monetary policy environment is uncertain and constantly changing. There is uncertainty about prevailing economic conditions and the nature and extent of economic shocks. There is model and parameter uncertainty and uncertainty regarding the market expectation process.

One approach would be to use precise, unambiguous words to portray complex facts without, at the same time, giving the impression that the world is more straightforward and secure than it actually is.

Striking the balance between the need for clear and simple messages and the need to adequately convey complexity is a constant challenge for central bank communication (Winkler, 2000). An additional difficulty stems from the need to address various target groups, including academics, the markets, politicians, and the general public. Such a broad spectrum may require a variety of communication channels geared to different levels of complexity or different time horizons.

\section{COMMUNICATION IN PRACTICE}

In order for this balancing act to be successful, central banks today use a variety of instruments (see Appendix Tables A1 and A2).

The wide array of communication instruments ranges from short press releases after monetary policy decisions to the publication of voting results, regular monthly or quarterly reports to the customary annual reports, as well as speeches and other contributions from central bank representatives.

The ECB has decided to publish neither the minutes of the Governing Council nor information about the voting behavior of its members, but instead holds an extensive monthly press conference directly after the Council meetings. The decision not to publish minutes and voting records has been a criticism frequently leveled at the ECB, casting doubts on its determination to be transparent and accountable (Buiter, 1999; de Haan and Eijffinger, 2000).

The critics often overlook the collegial nature of the ECB's decisionmaking process and the 
specific institutional circumstances under which the ECB operates as a supranational institution.

A decisionmaking body is always more than just the sum of its individual members, just as a decision is more than an act of voting. A decision is the result of collective deliberation and debate and cannot be reduced to a simple exchange of opinions (Issing, 1999). The public will ultimately judge the success of an institution against its mandate. What matters, then, is the collective responsibility of the monetary policy decisionmaking body for the decisions taken.

Any attempt to make individual policymakers personally accountable by publishing information about their voting behavior entails the risk that the public may attach more importance to individual opinions than to the relevant economic arguments. Particularly in a monetary union comprising several countries, the voting behavior of national central bank governors in particular might be interpreted from a "national" perspective-irrespective of how the members cast their votes and their reasons for doing so (see also Eijffinger and Hoeberichts, 2002, and Neumann, 2002, p. 360).

In its communication policy and its choice of medium, form, and content, a central bank needs to take into account particular circumstances. As a new institution, the ECB was faced with high uncertainty when it first took over responsibility for the single monetary policy for a new currency area comprising eleven, later twelve, sovereign countries (see Issing, 2004).

Against this background, the ECB adopted its own approach to communication: From the beginning, it placed a premium on speaking "with one voice" and consensus in decisionmaking, while spelling out the underlying economic arguments clearly and consistently.

By publicly announcing an explicit monetary policy strategy and a quantitative definition of price stability in 1998, the ECB has provided the basis for a high degree of credibility from the very beginning and has also highlighted its commitment to be open and transparent.

The public announcement of a quantitative definition of price stability helps the public to better monitor and assess the performance of the
ECB. Furthermore, the ECB, like many other central banks, describes the analytical framework used for its internal decisionmaking and explains which models, methods, and indicators form the basis of its decisions and assessments. A publicly announced strategy provides guidance for the markets, enabling them to form expectations more efficiently, enabling them to better anticipate interest rate decisions. ${ }^{5}$

The President's monthly press conference provides a timely and comprehensive summary of the monetary policy-relevant assessment of economic developments. It is structured along the lines of the ECB's monetary policy strategy and its text is agreed upon by the Governing Council. Questions from journalists are then answered, with the written transcript of the press conference published on the ECB's website only a few hours later.

The ECB decided to adopt a regular real-time communication tool instead of publishing with some delay. ${ }^{6}$ Immediate communication avoids the risk that a delay in the announcement of the reasons behind the monetary policy decision could affect the markets and increase volatility.

Overall, the ECB's communication policy is an expression of general principles and it has also been shaped by the particular challenges it faced as a new institution.

5 Empirical tests show that, with regard to the predictability of its decisions, the ECB's communication policy will easily stand up to any comparison (see, for example, Gaspar, Pérez-Quirós, and Sicilia, 2001; Bernoth and von Hagen, 2004; and Bank for International Settlements, 2004, p. 86; also, Poole and Rasche, 2003, provide evidence regarding the Federal Reserve).

6 The term "minutes," per se, directly implies transparency and authenticity regarding the course of a meeting. In this sense, the tradeoff between immediate and delayed publication (whether longer or shorter) is often overlooked. The Federal Open Market Committee discussed this in its January 27-28, 2004, meeting (see FOMC Minutes [sic!], 2004): "In further discussion the members reviewed the potential value and drawbacks of accelerating the publication of Committee minutes. Possible benefits would include the provision of more complete information sooner after meetings on the considerations that led the Committee to adopt the current stance of policy. Some members expressed concern, however, that accelerated release of the minutes might have the potential to feed back adversely on the deliberations of the Committee and on the minutes themselves. The members also emphasized the importance of allowing sufficient time for them to review and comment on the minutes and for reconciling differences of opinion among the members of a large and geographically dispersed committee. On December 14, 2004, the FOMC decided to expedite the release of its minutes to three weeks after the date of the policy decision. 


\section{CONCLUSION}

If there were any general conclusion to be drawn on the subject of "Communication, Transparency, and Accountability," then it would be this: None of these elements should be considered in isolation. Their interdependence stems from the monetary policy mandate and the position of the central bank in society. The central bank is not only obliged to fulfill its mandate, it must also provide society with convincing reasons for its actions. Whatever the external perception of the central bank, there must be no doubt that all communications are made to the best of its knowledge and belief.

\section{REFERENCES}

Adam, Klaus. "Optimal Monetary Policy with Imperfect Common Knowledge.” CEPR Discussion Paper No. 4594, Centre for Economic Policy Research, September 2004.

Bank for International Settlements. 74th Annual Report: 1 April 2003-31 March 2004. Basel, Switzerland: June 28, 2004.

Bernoth, Kerstin and von Hagen, Jürgen. "The Euribor Futures Market: Efficiency and the Impact of ECB Policy Announcements." International Finance, Spring 2004, 7(1), pp. 1-24.

Blackwell, David. "Equivalent Comparisons of Experiments." Annals of Mathematical Statistics, June 1953, 24(2), pp. 265-72.

Blinder, Alan S. Central Banking in Theory and Practice. Cambridge, MA: MIT Press, 1998.

Brunner, Karl. "The Art of Central Banking," in Hermann Göppl and Rudolf Henn, eds., Geld, Banken und Versicherungen. Volume 1. Königstein, 1981.

Buiter, Willem H. "Alice in Euroland." Journal of Common Market Studies, June 1999, 37(2), pp. 181-209.

Committee on Finance and Industry, Minutes of
Evidence, Volume I, printed and published by His Majesty's Stationary Office, London, 1931.

de Haan, Jakob and Eijffinger, Sylvester C.W. "The Democratic Accountability of the European Central Bank: A Comment on Two Fairy-Tales." Journal of Common Market Studies, September 2000, 38(3), pp. 393-407.

Eijffinger, Sylvester C.W. and Hoeberichts, Marco. "Central Bank Accountability and Transparency: Theory and Some Evidence." International Finance, Spring 2002, 5(1), pp. 73-96.

Eucken, Walter. Grundsätze der Wirtschaftspolitick. Edith Eucken and Karl Paul Hensel, eds. Second Edition. Tübingen: Mohr, 1995.

European Central Bank. "Monetary Analysis in Real Time.” Monthly Bulletin, October 2004, pp. 43-66.

Faust, Jon and Svensson, Lars E.O. "Transparency and Credibility: Monetary Policy with Unobservable Goals." International Economic Review, May 2001, 42(2), pp. 369-97.

Federal Open Market Committee. Minutes. Washington, DC: Board of Governors of the Federal Reserve System, January 27-28, 2004.

Friedman, Benjamin M. "Why the Federal Reserve Should Not Adopt Inflation Targeting," presented at the 2004 American Economic Association Meeting in San Diego; International Finance, March 2004, 7(1), pp. 129-36.

Friedman, Milton. A Program for Monetary Stability. New York: Fordham University Press, 1960.

Gaspar, Vítor; Pérez-Quirós, Gabriel and Sicilia, Jorge. "The ECB Monetary Policy Strategy and the Money Market." International Journal of Finance and Economics, October 2001, 6(4), pp. 325-42.

Goodfriend, Marvin. "Monetary Mystique: Secrecy and Central Banking." Journal of Monetary Economics, January 1986, 17(1), pp. 63-92.

Hirshleifer, Jack. "The Private and Social Value of Information and the Reward to Inventive Activity." American Economic Review, September 1971, 61(4), pp. 561-74. 
Hirshleifer, Jack. "Speculation and Equilibrium: Information, Risk, and Markets.” Quarterly Journal of Economics, November 1975, 89(4), pp. 519-42.

Issing, Otmar. "Rationale Erwartungen-im Jahre 67 vor Christus.“ Kyklos, 1985, 38(1), pp. 104-5.

Issing, Otmar. "The Eurosystem: Transparent and Accountable or 'Willem in Euroland'." Journal of Common Market Studies, September 1999, 37(3), pp. 503-19.

Issing, Otmar. Should We Have Faith in Central Banks? London: The Institute of Economic Affairs, 2002.

Issing, Otmar. "Geldpolitik für den Euroraum,”as published in: Perspektiven der Wirtschaftspolitik, November 2004, 5(4), pp. 381-404.

Kahneman, Daniel. "Maps of Bounded Rationality: Psychology for Behavioral Economics.” American Economic Review, December 2003, 93(5), pp. 144975 .

Kohn, Donald L. and Sack, Brian P. "Central Bank Talk: Does it Matter and Why?" Finance and Economics Discussion Series Paper No. 2003-55. Washington, DC: Board of Governors of the Federal Reserve System, 2003.

King, Mervyn. "The Institutions of Monetary Policy." The Ely Lecture 2004, Lecture at the American Economic Association Annual Meeting, San Diego, January 4, 2004.

McCallum, Bennett T. and Nelson, Edward. "Targeting vs. Instrument Rules for Monetary Policy.” Working Paper No. 2004-011A, Federal Reserve Bank of St. Louis, June 2004.

Morris, Stephen and Shin, Hyun Song. "Social Value of Public Information." American Economic Review, December 2002, 92(5), pp. 1521-34.
Neumann, Manfred J.M. "Transparency in Monetary Policy." Atlantic Economic Journal, December 2002, 30(4), pp. 353-65.

Orphanides, Athanasios and Williams, John C. "Imperfect Knowledge, Inflation Expectations, and Monetary Policy.” Finance and Economics Discussion Series Paper No. 2002-27. Washington, DC: Board of Governors of the Federal Reserve System, May 2002.

Poole, William. "Fed Transparency: How, Not Whether." Federal Reserve Bank of St. Louis Review, November/December 2003, 85(6), pp. 1-8.

Poole, William and Rasche, Robert H. "The Impact of Changes in FOMC Disclosure Practices on the Transparency of Monetary Policy: Are Markets and the FOMC Better 'Synched'?” Federal Reserve Bank of St. Louis Review, January/February 2003, 85(1), pp. 1-10.

Shannon, Claude E. "A Mathematical Theory of Communication.” Bell System Technical Journal, July and October 1948, 27, pp. 379-423 and 62356.

Sims, Christopher A. "Implications of Rational Inattention." Journal of Monetary Economics, April 2003, 50(3), pp. 665-90.

Thornton, Daniel L. "Monetary Policy Transparency: Transparent About What?" Working Paper 2002028B, Federal Reserve Bank of St. Louis, November 2002.

Winkler, Bernhard. "Which Kind of Transparency? On the Need for Clarity in Monetary Policy-Making." ECB Working Paper No. 26, European Central Bank, August 2000.

Woodford, Michael. Interest and Prices: Foundations of a Theory of Monetary Policy, Princeton:

Princeton University Press, 2003. 


\section{APPENDIX}

\section{Table A1}

\section{Communication: Instruments, Channels, and Target Groups}

\begin{tabular}{|c|c|c|c|}
\hline Instruments & Format & Channels & When \\
\hline \multicolumn{4}{|l|}{$\begin{array}{l}\text { Immediate announcement/explanation } \\
\text { of monetary policy decisions }\end{array}$} \\
\hline Press releases & Written & Website/hard copy & $\begin{array}{l}\text { Immediately after the } \\
\text { monetary policy meeting }\end{array}$ \\
\hline Press conference & $\begin{array}{l}\text { Verbal, with question and answer } \\
\text { session, sometimes includes } \\
\text { handing out of written background } \\
\text { information to media representatives } \\
\text { (e.g., opinion of the central bank } \\
\text { president, projections, etc.) }\end{array}$ & $\begin{array}{l}\text { Direct communication, } \\
\text { TV broadcast (live or } \\
\text { report later that day) }\end{array}$ & $\begin{array}{l}\text { Shortly after the } \\
\text { monetary policy meeting }\end{array}$ \\
\hline Transcript of the press conference & Written & Website/hard copy & $\begin{array}{l}\text { Shortly after the press } \\
\text { conference has finished }\end{array}$ \\
\hline
\end{tabular}

Supplementary information on
monetary policy decisions

Publication of the minutes of meetings Written Website/hard copy

Between 13 days and

8 weeks after the monetary policy meeting

Publication of voting behavior

Written

Website/hard copy

Together with the press release and/or minutes

of the meeting

Further information on monetary policy and economic developments

Reports (monthly bulletin, annual report, etc.) Written Website/hard copy

Publication of projections Written Website/hard copy

Publication of statistical data

Written

Website/hard copy

As soon as confirmed

\begin{tabular}{lcc}
\hline Publication of surveys & Written & Website/hard copy \\
\hline Public hearings/report to the legislature & Verbal/written & $\begin{array}{c}\text { Live reporting, print } \\
\text { media, website/hard copy }\end{array}$ \\
\hline Interviews & Verbal or written & TV, radio, and/or print media
\end{tabular}


Regularly

Brief, in some cases information is reduced to key words and formulae

$$
\begin{aligned}
& \text { Monetary policy decision, } \\
& \text { sometimes a brief } \\
& \text { explanation, monetary policy } \\
& \text { intentions, and announcement } \\
& \text { of voting behavior }
\end{aligned}
$$

Extensive
Explanation of the monetary policy decision, assessment of the current economic situation and its future development, sometimes comments

\begin{tabular}{|c|c|c|c|c|}
\hline Regularly & Extensive & $\begin{array}{l}\text { Explanation of the monetary policy } \\
\text { decision, assessment of the current } \\
\text { economic situation and its future } \\
\text { development, sometimes comments } \\
\text { on other policy areas }\end{array}$ & $\begin{array}{l}\text { General public, } \\
\text { media, markets }\end{array}$ & Yes \\
\hline Regularly & Extensive & $\begin{array}{l}\text { Explanation of the monetary policy } \\
\text { decision, assessment of the current } \\
\text { economic situation and its future } \\
\text { development, sometimes comments } \\
\text { on other policy areas }\end{array}$ & $\begin{array}{l}\text { General public, } \\
\text { media, markets }\end{array}$ & Yes \\
\hline Regularly & Extensive & $\begin{array}{l}\text { Information on the course of meetings } \\
\text { and discussions (presentation of the } \\
\text { reasons behind the monetary policy } \\
\text { decision, policy options, etc.) }\end{array}$ & $\begin{array}{l}\text { General public, } \\
\text { media, markets }\end{array}$ & No \\
\hline Regularly & Brief & $\begin{array}{l}\text { Presentation of the voting behavior, } \\
\text { explanation of dissenting positions }\end{array}$ & $\begin{array}{l}\text { General public, } \\
\text { media, markets }\end{array}$ & No \\
\hline
\end{tabular}
on other policy areas

\begin{tabular}{|c|c|c|c|c|}
\hline $\begin{array}{l}\text { Monthly/quarterly/ } \\
\text { annually }\end{array}$ & Extensive & $\begin{array}{l}\text { Analysis of monetary policy issues } \\
\text { and assessment of the current economic } \\
\text { environment, special topics, etc. }\end{array}$ & $\begin{array}{l}\text { General public, } \\
\text { media, markets }\end{array}$ & Yes \\
\hline Quarterly/biannually & Extensive & & $\begin{array}{l}\text { Analysts, ECB } \\
\text { observers, interested } \\
\text { members of the public }\end{array}$ & Yes \\
\hline Regularly & Extensive & $\begin{array}{l}\text { Money and banking statistics, } \\
\text { balance of payments statistics, etc. }\end{array}$ & $\begin{array}{c}\text { Analysts, ECB } \\
\text { observers, interested } \\
\text { members of the public }\end{array}$ & Yes \\
\hline Regularly & Extensive & & $\begin{array}{l}\text { Analysts, interested } \\
\text { members of the public }\end{array}$ & Yes \\
\hline Regularly & Extensive & $\begin{array}{l}\text { Explanation of monetary } \\
\text { answering of questions }\end{array}$ & $\begin{array}{l}\text { Politicians, ECB } \\
\text { observers, interested } \\
\text { members of the public }\end{array}$ & Yes \\
\hline Regularly & Brief to extensive & $\begin{array}{l}\text { Key monetary policy issues (mandate, } \\
\text { strategy, decisions), special topics, } \\
\text { current problems regarding economic } \\
\text { policy (fiscal policy, structural policy), } \\
\text { topics of regional interest, etc. }\end{array}$ & $\begin{array}{l}\text { National or regional } \\
\text { public, media, markets }\end{array}$ & Yes \\
\hline
\end{tabular}

General public, Yes media, markets

(cheras




\section{Table A1 cont'd}

\section{Communication: Instruments, Channels, and Target Groups}

\begin{tabular}{|c|c|c|}
\hline Instruments & Format & Channels \\
\hline \multicolumn{3}{|c|}{$\begin{array}{l}\text { Further information on monetary } \\
\text { policy and economic developments }\end{array}$} \\
\hline Speeches & Verbal & $\begin{array}{c}\text { Direct interaction; TV, radio, } \\
\text { and/or reporting in the media } \\
\text { (in most cases also website/hard copy) }\end{array}$ \\
\hline Briefings & Verbal & $\begin{array}{l}\text { Central bank representatives } \\
\text { meet with journalists in person }\end{array}$ \\
\hline \multicolumn{3}{|c|}{ Monetary policy research } \\
\hline Research papers & Written & Publications in hard copy/on website \\
\hline Conferences & Verbal/written & $\begin{array}{l}\text { Direct interaction and open dialogue, } \\
\text { sometimes with media presence, } \\
\text { subsequently also website/hard copy }\end{array}$ \\
\hline
\end{tabular}

Transfer of monetary policy knowledge

Presentations/visitor groups Verbal Direct interaction

Information leaflets Written Website/hard copy

Video/video games Audio-visual Website/presentation

School competitions $\quad$ Verbal and written $\quad$ Direct interaction


Key monetary policy issues (mandate, strategy, decisions), special topics, current problems regarding economic policy (fiscal policy, structural policy),

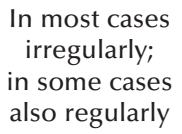

Extensive

Regularly

Regularly

Regularly

Brief to extensive

Regularly $\quad$ Brief to extensive

Regularly

Brief to extensive

Regularly

Extensive
Explanation of reactions, opinions, central bank assessments, in order to make monetary policy decisions more intelligible
Range from a simple presentation topics of regional interest, etc.

Range from a simple presentation

to a detailed explanation of basic monetary policy issues

Specific

Yes

Specialized fields, studies on monetary policy from a general

Academics, interested

Yes and academic point of view

Specialized fields, studies on monetary policy from a general and academic point of view

Media representatives Yes

members of the public

Academics, interested members of the public

Yes to a detailed explanation of basic monetary policy issues

School pupils, students, Yes

CEOs, interested members of the public

Range from a simple presentation

Children, teenagers, Yes to a detailed explanation of basic monetary policy issues teachers, students, interested members of the public

Children, teenagers, Yes teachers, students, interested members of the public

Teenagers, teachers No 
Table A2

Communication of Policy Decisions of Selected Central Banks

\begin{tabular}{|c|c|c|c|c|c|}
\hline Central banks/countries & ECB & Czech Republic & Norway & Poland & Sweden \\
\hline \multicolumn{6}{|l|}{$\begin{array}{l}\text { EARLY COMMUNICATION ON POLICY } \\
\text { DECISIONS } \\
\text { Announcement of policy decision }\end{array}$} \\
\hline Press release & Yes & Yes & Yes & Yes & Yes \\
\hline Frequency (times per year) & 12 & 12 & 9 & 12 & 8 \\
\hline After all monetary policy meetings? & Yes & Yes & Yes & Yes & Yes \\
\hline \multicolumn{6}{|l|}{$\begin{array}{l}\text { Explanation of policy decisions } \\
\text { Press release }\end{array}$} \\
\hline More than just the decision? & No & No & Yes & No & Yes \\
\hline Number of pages & No & No & 3 & No & $1 \frac{1}{1} 2$ \\
\hline \multicolumn{6}{|l|}{$\begin{array}{l}\text { Press conference } \\
\text { When is there a press conference? }\end{array}$} \\
\hline Frequency (times per year) & 11 & 12 & 9 & 12 & $\begin{array}{l}\text { Quarterly and } \\
\text { if rates are } \\
\text { changed }\end{array}$ \\
\hline After all monetary policy meetings? & $\begin{array}{l}\text { Yes (except } \\
\text { in August) }\end{array}$ & Yes & Yes & Yes & No \\
\hline Since when? & December 1998 & 2000 & June 1999 & January 2001 & Early 1990s \\
\hline Delay after announcement & 45 minutes & $2-3$ hours & 45 minutes & $2-4$ hours & $\begin{array}{c}90 \text { minutes or } \\
4 \text { hours }^{3}\end{array}$ \\
\hline \multicolumn{6}{|l|}{$\begin{array}{l}\text { Practice for all press conferences } \\
\text { Support used }\end{array}$} \\
\hline Media & $\begin{array}{l}\text { "Introductory } \\
\text { statement" }\end{array}$ & $\begin{array}{l}\text { Presentation } \\
\text { with charts }\end{array}$ & $\begin{array}{l}\text { Summary of the } \\
\text { press release itself } \\
\text { and presentation } \\
\text { with charts }\end{array}$ & $\begin{array}{l}\text { "Information from a } \\
\text { meeting of the } \\
\text { Monetary Policy } \\
\text { Council" and } \\
\text { presentation with } \\
\text { charts and tables }\end{array}$ & $\begin{array}{l}\text { Presentation } \\
\text { with slides }\end{array}$ \\
\hline Length & 3 pages & 5-10 slides & $\begin{array}{l}5 \text { slides (more } \\
\text { on the Internet) }\end{array}$ & $\begin{array}{l}2-3 \text { pages and } \\
\text { around } 20 \text { slides }\end{array}$ & $\begin{array}{l}10 \text { slides on } \\
\text { average }\end{array}$ \\
\hline Published? & Yes & No & Yes & $\begin{array}{l}\text { Yes (the statement, } \\
\text { but not the slides) }\end{array}$ & Yes \\
\hline
\end{tabular}

Q\&A

Is there a Q\&A session?

Yes

Is a transcript published?

Yes

In which format?

Internet

Yes

Yes

Yes

Yes

Broadcasting

Is the press conference broadcast? Yes, live

No

Yes, live

Yes, but not always

Yes, live

In which format?

Bloomberg TV

No

Internet

TVNZ

Internet 


\begin{tabular}{|c|c|c|c|c|c|c|}
\hline Switzerland & U.K. & Australia & Canada & Japan & New Zealand & U.S. \\
\hline Yes & Yes & Yes & Yes & Yes & Yes & Yes \\
\hline 4 & 12 & 11 & 8 & $15-19$ & 8 & 8 \\
\hline Yes $^{1}$ & Yes & Yes & Yes $^{1}$ & Yes & Yes $^{1}$ & Yes \\
\hline Yes & $\begin{array}{l}\text { Yes (but at MPC's } \\
\text { discretion) }\end{array}$ & $\begin{array}{l}\text { Yes (but only if } \\
\text { rates changed) }\end{array}$ & Yes & Yes & Yes & Yes \\
\hline $3^{2}$ & $1 / 4$ & 1 & $1 / 2-1$ & $1 / 2^{2}$ & $1 / 2-1$ & $1 / 2$ \\
\hline Half-yearly & No & No & No & 16 (in 2004) & Quarterly & No \\
\hline No & No & No & No & Yes & No & No \\
\hline 1974 & No & No & No & October 2003 & Late 1999 & No \\
\hline No & No & No & No & A few hours & No & No \\
\hline "Introductory remarks" & No & No & No & $\begin{array}{l}\text { "The Bank's view" of } \\
\text { the "Monthly Report } \\
\text { of Recent Economic } \\
\text { and Financial Developments" } \\
\text { (after 1st meeting of } \\
\text { the month) }\end{array}$ & $\begin{array}{c}\text { Chapter } 1 \\
\text { ("Policy assessment") } \\
\text { of the "Monetary } \\
\text { Policy Statement" } \\
\text { (report) } 4\end{array}$ & No \\
\hline 3 pages & No & No & No & 2 pages & $1 / 2-1$ page and report & No \\
\hline Yes & No & No & No & Yes & Yes & No \\
\hline Yes & No & No & No & Yes & Yes & No \\
\hline No & No & No & No & $\mathrm{No}^{5}$ & No & No \\
\hline No & No & No & No & $\mathrm{No}^{5}$ & No & No \\
\hline Yes, sometimes, live & No & No & No & $\begin{array}{c}\text { Yes, just after } \\
\text { end of conference }\end{array}$ & Yes, live & No \\
\hline Bloomberg TV & No & No & No & Bloomberg TV & Telesky TV & No \\
\hline
\end{tabular}




\section{Table A2 cont'd}

\section{Communication of Policy Decisions of Selected Central Banks}

\begin{tabular}{|c|c|c|c|c|c|}
\hline Central banks/countries & ECB & Czech Republic & Norway & Poland & Sweden \\
\hline \multicolumn{6}{|l|}{$\begin{array}{l}\text { Support available at some } \\
\text { press conferences }\end{array}$} \\
\hline Document & Section on projections & & "Inflation Report" & & "Inflation Report" \\
\hline Frequency & Quarterly & & 3 times a year & & Quarterly \\
\hline Number of pages & 5 & & 70 & & 60 \\
\hline When is it available? & At end of conference & & $\begin{array}{l}\text { When decision } \\
\text { is announced }\end{array}$ & & $\begin{array}{l}\text { When decision } \\
\text { is announced }\end{array}$ \\
\hline \multicolumn{6}{|c|}{$\begin{array}{l}\text { SUBSEQUENT COMMUNICATION } \\
\text { (EXCLUDING SPEECHES) } \\
\text { Minutes }\end{array}$} \\
\hline Minutes published? & No & Yes & No & No & Yes \\
\hline Number of pages & No & $1-2$ & No & No & $5-9$ \\
\hline Delay & No & 12 days & No & No & 2 weeks \\
\hline \multicolumn{6}{|l|}{ Other publications } \\
\hline Publication or media & "Monthly Bulletin" & "Inflation Report" & & "Inflation Report" & \\
\hline
\end{tabular}

After all monetary policy meetings? $\quad$ Yes $\quad$ No, quarterly $\quad$ No, 4 times per year

Timing 1 week after 1 week after $\quad 1$ week after

NOTE: The table focuses on pre-scheduled monetary policy meetings, unless otherwise specified. Frequencies and lengths of documents are approximate (in terms of comparable pages in the ECB's Introductory Statements). Where the documents are reports, their lengths are not indicated (as they depend inter alia on the layout used and are not easily comparable).

Country notes: ${ }^{1}$ In the cases of Switzerland, Canada, and New Zealand, dates of policy-decision releases instead of meeting dates are pre-announced. ${ }^{2}$ Switzerland: Half a page for half-yearly meetings (followed by further explanation at the press conference) and three pages for the other two meetings. Japan: About half a page if the stance of monetary policy is kept unchanged, somewhat longer otherwise (e.g., new measures taken). ${ }^{3}$ Sweden: Twice a year the Governor appears before the finance committee of the Riksdag. On these occasions, the press release is published at $9 \mathrm{a} . \mathrm{m}$. and the press conference starts at $1 \mathrm{p} . \mathrm{m}$. ${ }^{4} \mathrm{New}$ Zealand: Released at the media lock-ups for four of the eight interest rate decisions throughout the year. ${ }^{5}$ Japan: Minutes of the conference are posted on the Internet on the day after the conference. ${ }^{6}$ United States: The Federal Reserve System publishes a number of reports that provide considerable additional background on monetary policy decisions, including the semi-annual monetary policy report to Congress. 


\begin{tabular}{|c|c|c|c|c|c|c|}
\hline Switzerland & U.K. & Australia & Canada & Japan & New Zealand & U.S. \\
\hline & No & No & No & $\begin{array}{l}\text { "The Bank's view" of } \\
\text { "Outlook for Economic } \\
\text { Activity and Prices" }\end{array}$ & & No \\
\hline & No & No & No & Twice a year & & No \\
\hline & No & No & No & $3-4$ & & No \\
\hline & No & No & No & $\begin{array}{l}\text { Before press } \\
\text { conference starts }\end{array}$ & & No \\
\hline No & Yes & No & No & Yes & No & Yes \\
\hline No & 20 & No & No & $15-30$ & No & $7-10$ \\
\hline No & 13 days & No & No & 4-6 weeks & No & 5-8 weeks \\
\hline $\begin{array}{l}\text { "Quarterly } \\
\text { Bulletin" }\end{array}$ & $\begin{array}{l}\text { "Inflation Report" } \\
\text { and press } \\
\text { conference }\end{array}$ & $\begin{array}{l}\text { "Statement on } \\
\text { Monetary Policy" } \\
\text { (report) }\end{array}$ & $\begin{array}{l}\text { "Monetary Policy } \\
\text { Report" } \\
\\
\end{array}$ & $\begin{array}{l}\text { a) "Monthly Report of } \\
\text { Recent Economic and } \\
\text { nancial Developments" } \\
\text { "Outlook for Economic } \\
\text { Activity and Prices" }\end{array}$ & & $\begin{array}{c}\text { Report } \\
\text { to Congress }\end{array}$ \\
\hline Yes & No, quarterly & No, quarterly & $\begin{array}{c}\text { No, biannual } \\
\text { and two updates }\end{array}$ & $\begin{array}{l}\text { a) No, monthly } \\
\text { b) Twice a year } \\
\text { (for 2nd meeting } \\
\text { in month: April } \\
\text { and October) }\end{array}$ & & No, biannual \\
\hline $\begin{array}{l}\text { Approximately } \\
5 \text { weeks after }\end{array}$ & 6 days after & Between meetings & $\begin{array}{c}2 \text { days after } \\
\text { announcement }\end{array}$ & $\begin{array}{l}1 \text { working day after } \\
\text { a) } 1 \text { st meeting } \\
\text { of month or } \\
\text { b) } 2 \text { nd meeting } \\
\text { of month } \\
\text { (twice a year) }\end{array}$ & & \\
\hline
\end{tabular}


